\title{
Reflections on the productive chain of sustainability: oriented product
}

Luciane Cristina Ribeiro dos Santos

lu.ribeirocrs@hotmail.com

Pontifícia Universidade Católica do Paraná. Curitiba. Paraná. Brasil.

Osiris Canciglieri Junior osiris.canciglieri@pucpr.br Pontifícia Universidade Católica do Paraná. Curitiba. Paraná. Brasil.

Carlos Alberto Cioce Sampaio carlos.cioce@gmail.com

FURB. Blumenau. Santa Catarina. Brasil.

\begin{abstract}
The study aimed to identify the relevant researches that address the production chain theme with a focus on sustainability-oriented products. To achieve the proposed objective, a bibliometric research with content analysis was carried out. The research considered the following themes: supply chain management, production chain and sustainable product. The search platform used for data collection was the Brazilian CAPES database, which resulted in 2,052 articles. Based on data inclusion and exclusion criteria, 30 articles were selected as the most important to perform the content analysis. It became clear that the management of the production chain and its sustainable operations constitute a challenge for companies that seek and develop their inter-organizational skills and for all the actors involved in the chain. In general, the study points out that the challenges faced by management professionals are still associated with the incorporation of sustainability into their manufacturing processes. On the other hand, literature is rich in management learning associated with sustainability. Thus, the result of this study is relevant, as it is associated with the conceptual systematization that presupposes management guidelines for the product's productive chain that incorporates sustainability. Such learning can be able to serve as parameters for the promotion of sustainable development.
\end{abstract}

PALAVRAS-CHAVE: Management; Productive chain; Product oriented to sustainability. 


\section{INTRODUÇÃO}

Sustainability was included on the agenda of public and private institutions and society as an entire in the face of the environmental problems that the planet has faced, starting with the first delimitations established in 1972 at the United Nations Conference on the Environment in Sweden. Since 1972, United Nations Organizations have discussed progress on the issue of sustainability in all its editions. In 2017, the United Nations World Commission took a new step towards sustainable development and proposed seventeen-millennium goals to be implemented by 2030. Among the millennium goals, this study highlights sustainable production and consumption.

Thus, sustainable products are understood as one of the solutions to meet social needs and demands and contribute to a more sustainable environment throughout the product's life cycle (Brundtland, 1987). The product life cycle refers to the management that considers the entire product cycle, from the initial project phase, through the product manufacturing process, destination (final consumer) to reuse and disposal (Manzini and Vezzoli, 2008). In this way, integrating all the links involved in the production process, called the production chain.

Since the period of introduction of sustainable development concepts, it is being "the development that satisfies the needs of the present, without compromising the satisfaction of the needs of the next generations" (Brundtland, 1987). The term sustainability has been gaining prominence, especially in industry, due to the inefficiency of products and production processes in the use of resources when dealing with environmental issues under a logic of productivity of resource use, closely associated with innovation and competitiveness. In line with sustainable production is sustainable consumption, also known as conscious consumption, and related to product acquisition practices at the limit of basic human needs, this act helps to maintain natural resources and preserve the environment.

So, what are the relevant researches that address the thematic production chain associated with the product aimed at sustainability? Thus, the objective of the study was to identify the main researches that address the production chain theme with a focus on the product-oriented to sustainability. In this way, it would be possible to reflect on the management of the productive chain of productoriented to sustainability, thus understanding, how the referred themes could be aligned and understood as integral parts of the management of the production chain.

To achieve the proposed objective and answer the research problem, a systematic literature review with content analysis was carried out. The data for analysis were collected in the database of the Brazilian CAPES journals portal, which includes international indexed databases. The search took place based on the selection of the following keywords: green supply chain management, productive chain, sustainable product, green product and conscious consumption, obtaining 2,052 articles. Based on the inclusion and exclusion criteria, 30 articles were selected as the most relevant to perform the content analysis.

The articles were structured in 4 sections based on this introduction, which contemplates the research problem and the general objective of the study. Section two presents the methodological procedures used for the development of the 
research. Section three contemplates the results of the research with the content analysis of the main selected researches and finally, the conclusions.

\section{METHOD}

The study was developed from bibliometric research and content analysis. For data collection, the Brazilian CAPES journal portal was used, which is a Brazilian virtual library, considered as an essential information collection tool. The portal has a collection of more than 40,000 (forty thousand) journals and another 546 databases referenced in all areas of knowledge. Scopus, Web of Science and Emerald are some of these bases, thus justifying the use of the portal as a data collection tool.

The search on the platform took place from October to December of 2017 with updates in 2018. We chose to use a sentence composed of keywords with terms in English to search for articles relevant to the study, namely: "green supply chain management" OR ("sustain* product * chain management" AND "product * sustain*") OR "product * green" AND "conscious consumption". The use of Boolean terms (AND, OR and NOT) and wildcards (* and "') helped to filter the search for the main searches for the job.

In return, 2,052 (two thousand and fifty-two) articles were found. It should be noted that the data were not filtered by year. These results were filtered using data inclusion and exclusion criteria. The data inclusion criteria were peer-reviewed, only articles, English language, primary data, contains the keywords. The exclusion criteria were duplication of titles, secondary study, adaptation to the research context, the low impact factor (JCR and SJR). At the end of the material classification process, 30 (thirty) works were selected to perform the content analysis that is presented in section 3 .

\section{THOUGHTS ON THE MANAGEMENT OF THE SUSTAINABILITY-ORIENTED PRODUCT CHAIN}

From the methodological process described previously, it resulted in a bibliographic portfolio of 30 (thirty) articles. Concerning the space-time dimension, identified articles were published between from 1971 to 2018 as shown in graph 1.

Graph 1 - the year of publication of the documents highlighted in the survey

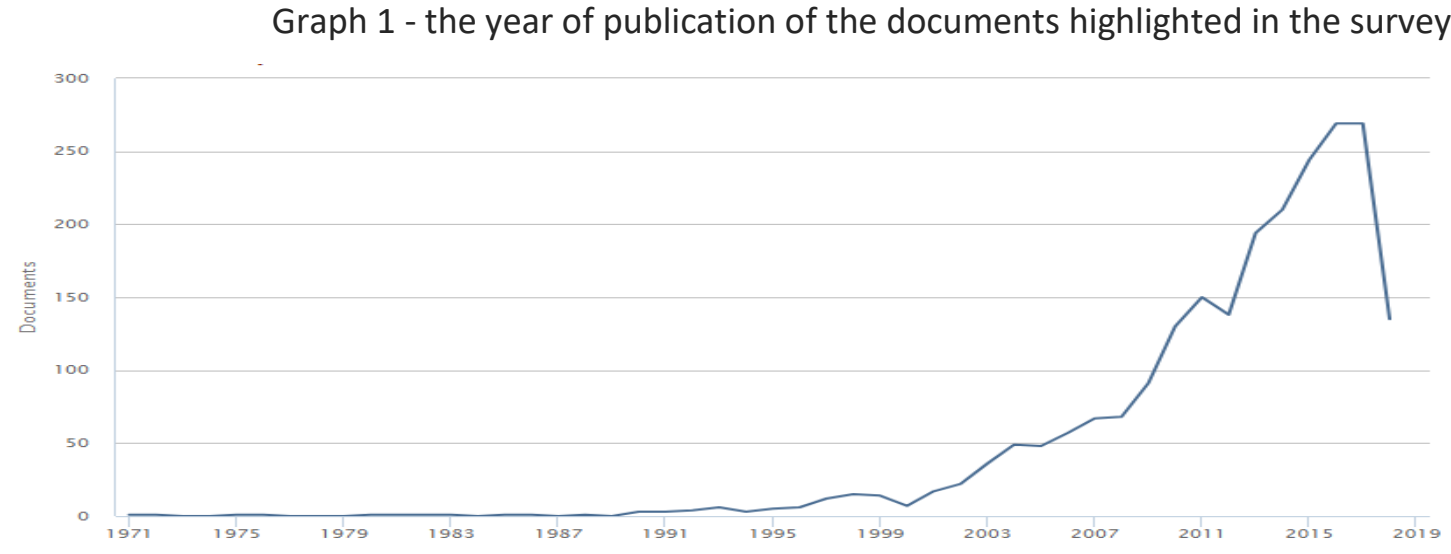

Source: the authors. 
It can be observed from Figure 1; there is a growing number of publications between the years 1971 to 2018 , it is suggested so that the subject is in vogue. From the analyzed articles, it is seen that $48 \%$ of the documents deal of literature review, $41 \%$ conducted a case study, and $10 \%$ took advantage of the survey. With the analysis it was revealed that some articles are correlated by address next themes, namely: supply chain, operations management (OM) sustainable, sustainable product, the sustainable business chain of green supplies, supply chain, operations management, consumption conscious, project management, product design, evaluation of product life-cycle management, and corporate sustainability report are some examples.

The articles by Kleindorfer et al., (2005), Corbett (2009), Abdul-Rashid et al., (2017) answer important questions related to the integration of sustainability into operations or called sustainable manufacturing practices by companies. In the work of Corbett (2009), a vision of operations management integrated with sustainability was presented, analyzing the idea of sustainable development applied to the business area. In the text, the author presents that sustainable development arises based on the product life cycle and on the pillars of sustainability, that is, the Triple Botton Line, aiming to demonstrate the importance of this integration in the provision of information and typologies for the management of sustainable operations.

The authors describe the three pillars as economic sustainability, that is: companies that develop long-term business activities, with concern for their performance in terms of cost, efficiency and competitiveness. The issue of environmental sustainability refers to concerns about the impacts and risks that the company may cause to the environment; the emission of gases is an example. The issue of social sustainability refers to the concern for the well-being of society, also known as socio-environmental sustainability, as people are directly involved with the environment.

Drake and Spinler (2013) and Epstein et al. (2015) address sustainability and their integration with companies' operational processes in their work. Epstein et al. (2015) developed the work based on field research and interviews with professionals from companies such as Nike, Procter \& Gamble and Nissan (all located in North America). The authors specifically investigated how managers are dealing with trade-offs linked to social, environmental and financial performance simultaneously. According to Paiva et al. (2004), the trade-off is characterized by the incompatibility between two or more criteria of competitiveness; that is, the improvement of one may disadvantage the other. This concept originated from the work of Skinner (1969), which indicated that the productive sector would contribute to the formation of the companies' strategy. For Silveira and Slack (2001), the trade-off must be seen in a production line that needs constant improvement.

Thus, in the article by Epstein et al. (2015) also highlights the importance of thinking about the business, linked to social and environmental objectives. For managers who can maintain business prospects simultaneously, it would be possible to achieve financial goals and achieve their social and environmental goals. Such an alternative or perspective is called the trade-off of the financial relationship with social and environmental verses, which are based on the premise that financial objectives must be balanced according to social and environmental considerations. Thus, it was presented that it would be possible to use 
organizational pressures, exerted through suppliers, customers and the government, for example, creatively as a source of new ideas and innovation, instead of seeing them as impediments to effective decision making.

The research by Drake and Spinler (2013) carried out from a literature review on the subject of operations management and reports from a survey with Paul Kleindorfer, a precursor in the field of Sustainable Operations Management (sustainable OM), sought to identify the contribution of operation management in support for sustainable operations management. Therefore, it is emphasized in the text that operations management has great potential in performing solutions to the challenges arising from sustainability.

Among the actions mentioned in the text that can determine the impact of sustainability and naturally represent the intersection of OM flows, the implementation of product design, technology and supply chain management was highlighted. In the study by Kleindorfer et al. (2005), the authors start from the premise that the challenges that management professionals have been facing in the last decades are to integrate their operations with sustainability issues, pointing out the three sustainability guidelines: environmental, social and economic (TBL). The authors addressed the principles of Total Quality Management (TQM) and Just-in-time (JIT), which are management tools linked to organizational operations.

The work shows that the evolution of sustainable operation management based on the TBL integrates the processes of green product, development and lean production management and product supply chains in closed circuit. Supply chains form a closed-loop when they are managed in a coordinated way towards common goals of maximizing gains and risk management, in a triple bottom line (TBL) perspective (Kleindorfer et al., 2005). In summary, lean production management refers to a methodology that aims to eliminate waste. Management is conducted through the application of five principles: i) to identify values through the client's perspective; ii) map the flow of values; iii) take actions that create value flow; iv) meet only the demands and; v) seek perfection. All information to drive this strategy comes from customers and aims to improve processes to eliminate waste (Womack et al., 1996).

In this way, sustainable operation management can be understood as a set of skills and concepts that allow a company to structure its business processes. It is used to obtain a competitive advantage around its active capital, without sacrificing the needs of internal and external stakeholders and taking into account the impact of its operations on society and the environment. However, Rashid et al. (2013) argued for a radical change in thinking about closed-circuit systems. They reported that for the sustainability of future societies, sustainable manufacturing strategies are needed with the conservation of resources and the environment as an integral part. In this perspective, closed-circuit supply chains are considered the most viable solution. On the other hand, its implementation within the prevailing open circuit product systems paradigm seems extremely complicated and practically unviable. Thus, they suggest a change in thinking about closed-circuit systems and present the new concept of Resource Conservative Manufacturing (ResCoM).

The ResCoM concept considers the conservation of energy, material and added value, combining waste prevention and environmental protection, as 
integrated components of the product design and development strategy (Rashid et al., 2013). They also presented the innovative idea of products with several life cycles, which the predefined duration is determined in the product design phase, requiring new design strategies and methodologies.

To succeed with this concept, ResCoM advocates a new approach to supply chain design and business models, in which customers are an integral part of industrial companies, and product design is effectively connected with supply chain design. Thus, products, supply chains and business models developed for open circuit product systems cannot cope with the dynamics of closed-circuit systems. The uncertainties associated with product returns are inherent to the conventional concept of the life cycle and closed-cycle systems. The ResCoM concept has much more capacity to deal with these uncertainties while developing sustainable closed-loop systems (Rashid et al., 2013).

In the work of Walton et al., (1998), the problem of integration and collaboration related to sustainability in the network of operations was discussed. In the work of Corbett (2009), Berns et al. (2009), Bocken et al. (2014), MarcelinoSádaba et al. (2015), Haanaes et al. (2012) and Unruh et al. (2016) had new demands from the sustainable development paradigm, related to sustainable business. Specifically, in work by Unruh et al. (2016), based on a survey conducted in 2015 with more than 3,000 managers and investors in organizations from more than 100 countries, the new ability of investors to deal with the existing relationships between corporate sustainability performance and performance was analyzed financial.

The text highlights the importance given to the image and commitment of companies to their internal and external public, as well as their concerns with the environment, which is no longer a trend to become a survival factor in the competitive market. It was possible to observe in the study that investors adopt attitudes, behaviours and actions that promote sustainability as a criterion for reliability. This reasoning identifies a paradigm shift in corporate culture, as corporations are concerned with their image concerning their interest groups, thus promoting corporate sustainability.

The works of Michelsen and Fet (2010), Seuring (2011), Liu et al. (2012), Ahi and Searcy (2013), Pagell \& Shevchenko (2014) Shashi et al. (2016) addressed sustainable supply chain management. Ferrer (2008), Gunasekaran and Spalanzani (2012) and Haanes et al. (2012) punctuate and clarify the role of sustainability in the management of a company's manufacturing and service operations. Ferrer (2008) shows that the focus on sustainability is increasingly ascending and that politicians and organizational leaders are adhering to the vision of long-term planning, thus disengaging from models that privilege immediate results (short term). In this sense, the long-term approach is aligned with performance and continuous improvement measures, which are introduced as necessary components to translate the sustainable corporate strategy into operations, using an integrated model that supports environmental quality and safety. The authors state that companies must adapt business strategies to seek the organization's success in a competitive scenario. In other words, in the absence of government regulations that make specific requirements for environmental protection, the manager must, for example, take care to incorporate environmental sustainability goals in his business strategies. 
Thus, the organizational strategy must be based on the sustainability pyramid, which is based on the TBL. That is, maximizing the productivity of resources at the company level, taking into account scarce environmental resources, such as energy and raw materials, instead of simply minimizing waste or pollution associated with a given product. Besides, non-compliance in the production process in any of the production areas increases the amount of waste that is generated, which affects environmental performance. Thus, organizations could influence key suppliers to adopt best practice practices (Ferrer, 2008).

As presented by Porter and Van Der Linde (1995), Seuring and Müller (2008b), Walton et al. (1998), Yan et al. (2015) and Chkanikova (2016), sustainability is an aspect of operation management that depends on relationships throughout the production chain system and chain of operations or links in the chain. However, the management of the production chain and its sustainable operations constitute a challenge for companies that seek and develop their inter-organizational skills and for all the actors involved in the chain. These organizations are called "focal companies" and are companies that adopt Corporate Social Responsibility (CSR).

According to the World Business Council for Sustainable Development, CSR can be understood as the continuous commitment of managers to adopt ethical behaviour and contribute "to economic development, while improving the quality of life of their" employees "and their families, the local community and society as a whole "(Melo Neto and Froes, 1999, p. 87). Corresponding to Seuring and Müller (2008b), the "focal company" would be the one that establishes rules, performs the management of the supply chain, has direct contact with the consumer, as well as projects the production of the production chain. Thus, it can be said that the focal company has a link that connects it with its entire production chain, is an important influencer for the realization of innovations for business models with implements of sustainable practices among the members of the chain. In this perspective, the objectives of productive chains.

\section{FINAL REMARKS}

Based on bibliometric and analytical research, this study sought to identify in the literature, the main researches that address the issues related to the production chain with a focus on sustainable consumption and product. Among the related themes identified in the study that showed greater relevance and incidence in the research were: supply chain, supply chain, sustainable operation management, sustainable product, sustainable business, productive chain, conscious consumption, responsible consumption, sustainable consumption, triple button line, product design, ecological or green design, product life cycle assessment, eco-label and sustainability indicators.

Based on reflections in order to understand how these themes could be aligned and understood as integral parts of the management of the production chain. It was found that, for this study, the supply chain can be considered a synonym for supply chain or supply. However, they are distinctly mentioned; these terminologies appeared in several works and are related when dealing with the production links.

When the authors referred to sustainable operation management, they were dealing with the process of managing operations to seek sustainability in an 
integrated process, that is, in all dimensions, whether social, environmental or economic. These being the dimensions of sustainability, which is an organizational context refers to the triple bottom line. Thus, the term of sustainable operations was related to other terms, such as sustainable business, sustainable product, product design, technology, green production chain, green supply chain, among others.

The management of the productive chain of the sustainable product can be considered as a methodological process aligned with several management instruments, namely: sustainability indicators, regulations and standards, such as the International Organization for Standardization (ISO), product life cycle assessment and triple bottom line. Even though the research has identified several management tools for the processes of integrating sustainability into production, managers still find it difficult to align management tools with sustainability issues. It is justified in the research, as many scholars in the area show that the challenges of management professionals are in the incorporation of sustainability in the production chain (Iles, 2007; Berns et al., 2009; Kleindorfer et al., 2012; Gunasekaran and Spalanzani, 2012; Vasileiadis et al., 2013; Epstein et al., 2015; Ding et al., 2015; Unruh et al., 2016; Unruh and Canciglieri Junior, 2020; Mattioda et al., 2013).

Although the study has presented numerous researches that addressed the productive chain, sustainable product and some studies that addressed sustainable consumption or conscious consumption, the results of the work indicate that currently in the literature there are no systemic studies that address the inter-organizational management of the production chain, products oriented towards sustainability and conscious consumption, only segmented works or correlating one or the other theme. Future research could contribute to the construction of a conceptual framework for the formulation of new hypotheses related to sustainable production and consumption, uniting the links of the productive chain in order to strengthen and integrate sustainability in the management models in the productive processes of organizations.

For the authors, it seems appropriate that future research should be able to bring together the concepts of supply chain management, incorporating the aspects of sustainability in the chain management models through tools, namely: product design, life cycle assessment product, triple bottom line and eco-labelling of the product presenting necessary information for consumers related to the sustainability or sustainable production process of the product. The management model oriented towards sustainability and conscious consumption needs to consider environmental costs, product quality, product price, occupational health and safety systems and environmental competencies for the selection of sustainable suppliers.

It is also suggested that the term conscious consumption can be aligned to the management model through the production process, thinking based on the role of organizations in encouraging and making products available in the market that meets the consumer's perspectives and demand, such as the absence of information relevant to the sustainable product. What makes the systematic study on the difficulties of conscious consumption. Thus, a proposal for future research that lists all the themes that were the subject of study is considered opportune, that is inter-organizational management of the production chain, sustainable product and conscious consumption. The theme thus becomes original. Thus, it is 
hoped that this study will serve as an inspiration for future research, with the objective of identifying management practices related to the themes suggested here, these practices being considered as alternative movements to development, in order to build a more sustainable world and contribute towards the Millennium Goals as proposed by the United Nations World Commission.

\section{Acknowledgement}

The authors would like to thank the Pontifical Catholic University of Paraná, for creating the Marcelino Champagnat award, with which the primary author was awarded for academic merit, thus being able to pursue a doctorate with no monthly fee. As well, we would like to thank the Brazilian Coordination for the Improvement of Higher Education Personnel (CAPES), the Brazilian Araucária Foundation and Brazilian National Council for Scientific and Technological Development (CNPq) for the financial support to carry out this research. 


\title{
Reflexões sobre a cadeia produtiva de produto orientado à sustentabilidade
}

\begin{abstract}
RESUMO
O objetivo do estudo foi identificar as principais pesquisas que abordam o tema cadeia produtiva com foco no produto orientado à a sustentabilidade. Para alcançar o objetivo proposto, foi realizada uma pesquisa bibliométrica com análise de conteúdo. A pesquisa considerou os seguintes temas: gestão da cadeia de suprimentos, cadeia produtiva e produto sustentável. A plataforma de busca utilizada para a coleta de dados foi a base CAPES brasileira, o qual resultou em 2.052 artigos. Com base em critérios de inclusão e exclusão de dados, 30 artigos foram selecionados como os mais importantes para realizar a análise de conteúdo. Ficou claro que a gestão da cadeia produtiva e suas operações sustentáveis constituem um desafio para as empresas que buscam e desenvolvem suas competências interorganizacionais e para todos os atores envolvidos na cadeia. Em geral, o estudo aponta que os desafios dos profissionais de gestão ainda estão associados à incorporação da sustentabilidade em seus processos de fabricação. Por outro lado, percebe-se que a literatura é rica em aprendizagem gerencial associada à sustentabilidade. Assim, o resultado deste estudo é relevante, pois está associado à sistematização conceitual que pressupõe diretrizes de gestão da cadeia produtiva do produto que incorpora a sustentabilidade. Tal aprendizado pode servir como parâmetros para a promoção do desenvolvimento sustentável.
\end{abstract}

PALAVRAS-CHAVE: Gestão; Cadeia produtiva; Produto orientado à sustentabilidade. 


\section{REFERÊNCIAS}

Abdul-Rashid, S., H., Sakundarini, N., Ghazilla, R., A., R., Thurasamy, R., 2017. The impact of sustainable manufacturing practices on sustainability performance. International Journal of Operations \& Production Management. 37, 182-204.

Ahi, P., Searcy, C., 2016. A comparative literature analysis of definitions for green and sustainable supply chain management. Journal of Cleaner Production. 52, 329-341.

Berns, M., Townend, A., Khayat, Z., Balagopal, B., Reeves, M., Hopkins, M. S., Kruschwitz, N., 2009. The business of sustainability: what it means to managers now. MIT Sloan Management Review. 51, 20-26.

Bocken, N.M.P., Short, S.W., Rana, P., Evans, S., 2014. A literature and practice review to develop sustainable business model archetypes. Journal of Cleaner Production. 65, 42-56.

Chkanikova, O., 2016. Sustainable Purchasing in Food Retailing: Interorganizational Relationship Management to Green Product Supply. Business Strategy and the Environment. 25, 478-494.

Corbett, L., M., 2009. Sustainable operations management: a typological approach. Journal of Industrial Engineering and Management. 2, 10-30.

Ding, H., Zhao, Q., Zhirong A., Jia Xu, Q. L., 2015. Pricing strategy of environmental sustainable supply chain with internalizing externalities, Original Research Article. International Journal of Production Economics. 170, 563-575.

Drake, D. F., Spinler, S., 2013. Sustainable Operations Management: An Enduring Stream or a Passing Fancy? Manufacturing \& Service Operations Management. 15, 689-700.

Epstein, M.J., Rejc Buhovac, A., Yuthas, K., 2015. Managing social, environmental and financial performance simultaneously. Long Range Planning. 48, 35-45.

Ferrer, G., 2008. Sustainability: What Does it Mean for the Operations Manager? Journal of Operations and Supply Chain Management. 1, 1-16.

Gunasekaran, A., Spalanzani, A., 2012. Sustainability of manufacturing and services: Investigations for research and applications. International Journal of 
Haanaes, K., Reeves, M., Velken, I. V. S., Audretsch, M., Kiron, D., Kruschwitz, N., 2012. Susteinability nears a tipping point. MIT Sloan Management Review. 52, 6974.

Kleindorfer, P.R., Singhal, K., Wassenhove, L.N.D., 2005. Sustainable Operations Management. Production and Operations Management. 14, 482-492.

Kremer, G. E., Haapala, K., Murat, A., Chinnam, R. B., Kim, Kyoung-yun, Monplaisir, L., Lei, T., 2016. Directions for instilling economic and environmental sustainability across product supply chains. Journal of Cleaner Production. 112, 2066-2078.

Liu, X., Yang, J., Qu, S., Wang, L., Shishime, T., Bao, C., 2012.

Sustainable Production: Practices and Determinant Factors of Green Supply Chain Management of Chinese Companies. Business Strategy and the Environment. 21, 1-16.

Luthra, S., Govindan, K., Kannan, D., Mangla, S. K., Garg, C. P., 2017. An integrated framework for sustainable supplier selection and evaluation in supply chains. Journal of Cleaner Production. 140, 1686-1698.

Marcelino-Sádaba, A., González-Jaen, L. F., Pérez-Ezcurdia, A., 2015. Using project management as a way to sustainability. From a comprehensive review to a framework definition. Journal of Cleaner Production. 99, 1-16.

Marchand, A., Walker, S. Product development and responsible consumption: designing alternatives to sustainable lifestyles. Journal of Cleaner Production. 16, 1163-1169.

Mark, P., 2014. Why Research in Sustainable Supply Chain Management Should Have no Future. International Journal of Supply Chain Management.50, 44-55.

Melo Neto, F., Froes, C., 1999. Responsabilidade Social \& Cidadania Empresarial, 1. Qualitymark.

Michelsen, O., Fet, A., M., 2010. Using eco-efficiency in sustainable supply chain management; a case study of furniture production. Clean Technologies and Environmental Policy. 12, 561-570.

Paiva, E.L., Carvalho, J. M. Jr., Fensterseifer, J. A., 2004. Estratégia de produção e de operações. Porto Alegre, Bookman. 
Porter, M. E., Van Der Linde, Claas., 1995. Green and competitive: ending the stalemate. Harvard Business Review. 73, 120-134.

Rashid, A., Asif, F. M.A., Krajnik, Peter., Nicolescu, C. M., 2013. Resource Conservative Manufacturing: an essential change in business and technology paradigm for sustainable manufacturing. Journal of Cleaner Production. 57, 166177.

Seuring, S., 2011. Supply chain management for sustainable products - insights from research applying mixed methodologies. Business Strategy and the Environment. 20, 471-484.

Seuring, S., Muller, M., 2008a. Core issues in sustainable supply chain management: a delphy study. Business Strategy and The Environment. 17, 455466.

Seuring, S., Muller, M., 2008b. From a literature review to a conceptual framework for sustainable supply chain management. Journal of Cleaner Production. 16, 1699-1710.

SHAO, J., 2016. Are present sustainability assessment approaches capable of promoting sustainable consumption? A cross-section review on information transferring approaches. Sustainable Production and Consumption. 7, 79-93.

Shashi, R., Singh, A., Shabani, R., 2016. The identification of key success factors in sustainable coldchain management: Insights from the Indian food industry. Journal of Operations and Supply Chain Management. 9, 01-16.

Silveira, G., Slack, N., 2001. Exploring the trade-off concept. International Journal of Operations and Production Management. 21, 949-964.

Skinner, W., 1969. Manufacturing - The missing link in corporate strategy. Harvard Business Review. 47, 5-14.

Ülkü, M. A., Hsuan, J., 2017. Towards sustainable consumption and production: Competitive pricing of modular products for green consumers. Journal of Cleaner Production. 142, 4230-4242.

Unruh, G., Kiron, D. K. N., Reeves, M., Rubel, H., Felde, A. M. Z., 2016. Investing For a Sustainable Future, MIT Sloan Management Review. 3-30. 
Walton, S. V., Handfield, R. B., Melnyk, S. A., 1998. The green supply chain: integrating suppliers into environmental management processes. International Journal of Purchasing and Materials Management. 34, 2-11.

Womack, J., Jones, D., Daniel, T., 1996. Lean Thinking: Banish Waste and Create Wealth in Your Corporation. Simon \& Schuster, New York.

Yan, B., Shi, S., Ye, B., Zhou, X., Shi, P., 2015. Sustainable development of the fresh agricultural products supply chain through the application of RFID technology. Technology Management. 16, 67-78.

Recebido: 08 mar. 2020

Aprovado: 08 abr. 2020.

DOI:10.3895/rbpd.v9n2.11931

Como citar: SANTOS, L. C. R.; JUNIOR, O. C.; SAMPAIO, C. A. C. Reflexões sobre a cadeia produtiva de produto orientado à sustentabilidade. R. bras. Planej. Desenv. Curitiba, v. 9, n. 2, p. 214-227, mai./ago.

2020. Disponível em: <https://periodicos.utfpr.edu.br/rbpd>. Acesso em: XXX.

Correspondência:

Luciane Cristina Ribeiro dos Santos

R. Imac. Conceição, 1155 - Prado Velho - Curitiba, PR

Direito autoral: Este artigo está licenciado sob os termos da Licença CreativeCommons-Atribuição 4.0

Internacional. 